\title{
Investment in Indian Gold Etfs Soaring
}

\author{
Dr.V.Latha Mba Phd ${ }^{1}$, D.Deepa $\mathrm{Mba}^{2}$ \\ ${ }^{1}$ director Department Management Studies Snr \& Sons College Coimbatore Tamil Nadu India - 61004 \\ ${ }^{2}$ phd Scholar Department Management Snr \& Sons College Coimbatore Tamil Nadu India - 61004
}

\begin{abstract}
Among all the investment alternatives available in the world, gold has shown better performance over years. In spite of its mediocre short term performance, Gold has constantly outperformed other conventional asset classes such as currencies, debt, equity and other commodities regardless of most of economic and market cycles with a CAGR of $17.1 \%$ in INR term and $14.5 \%$ in USD term for the past ten year period. However, there are a number of ways by which investment in gold can be made like gold ETFs and fund of funds, E-gold, stocks of gold mining companies, gold futures, gold bars, coins and biscuits, gold jewellery, etc. Out of these, ETFs are amongst the most popular investment tools. This paper attempts to the performance of gold ETFs. For this purpose, risk and return of Gold ETFs has been compared with the risk and return. Monthly closing prices from March 31, 2011 to March 31, 2016 have been taken. The empirical evidence concluded that the rising investment demand in India would prompt many fund houses to start new gold ETFs. Hence the performance of Gold ETFs is soaring in future.
\end{abstract}

Keywords: Gold ETFs, Risk, Return, Critical Appraisal

\section{Introduction}

Gold Exchange Traded Funds are witnessing a sharp spurt in volumes in India, with investors scurrying to pick up as many as they can lay their hands on. With over 30 mutual fund companies present in India, some 12 mutual fund houses have come up with gold ETFs. Investment awareness and the tremendous potential for gold investment in the form of ETFs are ensuring that companies line up many more in the upcoming years.

\section{About Gold Etf}

ETFs have several similarities to mutual funds. Like a Mutual Fund, an ETF is a pool or basket of investments. However, ETF's many times having lower expenses then a similar mutual fund in that there are no loads and the operating expenses are often lower. FINRA posted the following comparison of expenses on its website.

Another primary difference is that an ETF doesn't trade at the end of the day like a Mutual Fund. The price of the ETF is determined by investor demand at any given time during the trading day.

\section{Gold Etfs In India}

Gold Exchange Traded Funds (ETFs) are being traded in India since March 2007. Benchmark Asset Management Company Private Ltd. was the first to put in the proposal for gold ETF with the Securities and Exchange Board of India (SEBI). However, that is no longer offered on the exchange.

\section{Gold ETF schemes in India}

In the 9 years since the gold ETFs began trading in Indian stock exchanges, many financial firms have begun offering gold ETF schemes. The following 13 gold ETF schemes are available in India:

1. Birla Sun Life Gold ETF

2. Goldman Sachs Gold ETF

3. Religare Invesco Gold ETF

4. Quantum Gold Fund

5. SBI Gold ETF

6. IDBI Gold ETF

7. R*Shares Gold ETF

8. Axis Gold ETF

9. Kotak Gold ETF

10. ICICI Prudential Gold ETF

11. UTI Gold ETF

12. HDFC Gold ETF

13. Can Gold ETF 


\section{Choosing the right ETF scheme}

The profitability of Gold Exchange Traded Funds schemes can be determined by looking at the investment profiles of the scheme. The main factors to consider are:

- Assets under Management (AUM): AUM is defined as the market value of all the financial assets that a company manages for its investors. If a company has a high AUM value, it reflects on the high number of clients and portfolios that it handles.

- Net Asset Value (NAV): NAV is the value of the company's assets except the value of its liabilities. It is also the ETF's per-share value. NAV is arrived at by dividing the total value of all the securities in a firm's portfolio, except the liabilities, by the number of outstanding fund shares.

- Returns: The profits or income made by an ETF scheme or portfolio is known as returns.

\section{Performance In Gold Etfs}

\begin{tabular}{|l|l|l|l|l|l|}
\hline \multicolumn{2}{|c|}{$\begin{array}{l}\text { Ended } \\
\text { ANNUALIZED SHARPE RATIO OF GOLD ETFS }\end{array}$} & Returns \\
\cline { 2 - 6 } $\begin{array}{l}\text { Gose } \\
\text { Gold ETFs }\end{array}$ & $\mathbf{2 0 1 1 - 2 0 1 2}$ & $\mathbf{2 0 1 2 - 2 0 1 3}$ & $\mathbf{2 0 1 3 - 2 0 1 4}$ & $\mathbf{2 0 1 4 - 2 0 1 5}$ & $\mathbf{2 0 1 5 - 2 0 1 6}$ \\
\hline Axis Gold & NA & 0 & 0.05 & -0.01 & -0.07 \\
\hline Gold Bees & 0.03 & 0.03 & 0.05 & -0.02 & -0.07 \\
\hline Gold share & 0.04 & 0.03 & 0.05 & -0.02 & -0.01 \\
\hline HDFC & NA & 0.08 & 0.05 & -0.01 & -0.07 \\
\hline ICICI & NA & 0.05 & 0.04 & -0.01 & -0.06 \\
\hline Kotak Gold ETF & 0.03 & 0.03 & 0.05 & -0.01 & -0.07 \\
\hline Quantum Gold Fund & 0.03 & 0.03 & 0.05 & -0.01 & -0.06 \\
\hline Reliance Gold Fund & 0.03 & 0.03 & 0.05 & -0.01 & -0.07 \\
\hline Religare Gold ETF & NA & 0.06 & 0.05 & -0.01 & -0.06 \\
\hline SBI Gold ETF & 0.05 & 0.03 & 0.05 & -0.01 & -0.07 \\
\hline Birla Sunlife Gold ETF & NA & NA & 0.04 & NA & -0.05 \\
\hline IDBI Gold ETF & NA & NA & 0.1135 & -0.02 & -0.05 \\
\hline MG GOLD ETF & NA & NA & -0.02 & -0.06 & -0.02 \\
\hline
\end{tabular}

The Sharpe index assigns the highest values to assets that have best risk adjusted average rate of return. The risk free rate has been taken from the risk free rate of SBI on whole since it cannot be calculated on own. Sharpe ratio measures the total risk of the funds on the basis of return per unit of total risk. From the above table it is clear that SBI GOLD ETF performed well during the financial year 2013-2014 compared to other 4 years.

\begin{tabular}{|l|l|l|l|l|l|}
\hline ANNUALIZED TREYNOR RATIO OF GOLD ETFS \\
\hline \multirow{2}{*}{$\begin{array}{l}\text { Close } \\
\text { Gold ETFs }\end{array}$} & Ended & \multicolumn{5}{l|}{} \\
\cline { 2 - 6 } & $\mathbf{2 0 1 1 - 2 0 1 2}$ & $\mathbf{2 0 1 2 - 2 0 1 3}$ & $\mathbf{2 0 1 3 - 2 0 1 4}$ & $\mathbf{2 0 1 4 - 2 0 1 5}$ & $\mathbf{2 0 1 5 - 2 0 1 6}$ \\
\hline Axis Gold & NA & -0.01 & -2.02 & -0.22 & -2.44 \\
\hline Gold Bees & -8.77 & 0.84 & -2.17 & -0.21 & -0.59 \\
\hline Gold share & -3.24 & 0.36 & -1.44 & -0.19 & -1.21 \\
\hline HDFC & NA & 0.72 & -1.65 & -0.05 & -0.05 \\
\hline ICICI & NA & 0.31 & -2.33 & 307.13 & -1.13 \\
\hline Kotak Gold ETF & -3.91 & 0.81 & -1.16 & -0.15 & -0.69 \\
\hline Quantum Gold Fund & -83.51 & 0.71 & -2.26 & -0.29 & -1.19 \\
\hline Reliance Gold Fund & -12.33 & 0.55 & -1.34 & -0.18 & -0.61 \\
\hline Religare Gold ETF & NA & 0.67 & 0.59 & -1.24 & -0.78 \\
\hline SBI Gold ETF & -1.08 & 0.43 & 2.37 & -0.14 & -1.11 \\
\hline Birla Sunlife Gold ETF & NA & NA & 0.52 & 1.07 & -0.65 \\
\hline IDBI Gold ETF & NA & NA & -4.63 & 0.48 & -0.47 \\
\hline MG GOLD ETF & NA & NA & NA & -0.54 & -2.74 \\
\hline
\end{tabular}

Treynor is a measurement of the returns earned in excess of that which could have been earned on an investment that has no diversifiable risk per each unit of market risk assumed. Above Table shows the Treynor measures of Gold ETF listed in NSE. In the year 2010-2011 SBI performed well. It has been inferred from the table 4 that in the year 2013-2014 GOLD BEES and in the year 2012-2013 BIRLA Gold ETF has performed well. In the year 2014-2015 ICICI Gold ETF and 2015-2016 HDFC has performed well

\section{Empirical Results}

The performance of gold ETF is soaring year by year. However, it is difficult to compare these two by risk and return. Therefore, coefficient of variation has been used to compare the performance of gold with the ETF since higher the coefficient of variation higher is the variability and vice-versa. The results of the analysis are presented in the following table. 


\begin{tabular}{|l|l|l|l|}
\hline \multirow{2}{*}{ Year } & \multicolumn{3}{|l|}{ Gold ETFs } \\
\cline { 2 - 4 } & Risk & Return & C.V \\
\hline $2012-2013$ & 5.33 & 2.59 & 205.79 \\
\hline $2013-2014$ & 1.96 & 0.46 & 426.09 \\
\hline $2014-2015$ & 6.024 & -0.18 & -3346.9 \\
\hline
\end{tabular}

The above table makes it clear that the coefficient of variation of gold ETFs is less than the coefficient of variation of physical gold. It signifies that the gold ETFs have lesser variability as compared to the physical gold and hence the performance of gold ETFs is better than the performance of physical gold.

\section{India's Gold Demand Is Soaring Again}

Investors in India have ratcheted up their purchases in exchange-traded funds that aim to track the price of gold. For the month of February, gold ETF assets under management in India soared to 97.95 billion (b) rupees (US\$1.96B), up 161\% from a year ago. Data from the Association of Mutual Funds in India showed that total assets of gold ETFs jumped to the 97.95B rupee figure as of Feb, 29, from 37.44B rupees a year ago.

Analysts tracking the scene said other than a rise in traditional investment routes in gold, a sharp rise in the price of gold over the past year has pushed many gold retail investors to the mutual fund route. "As gold prices continue to soar, more asset management companies that run mutual fund schemes have begun to launch gold-related plans," said Sunder Manish, bullion analyst.

Analysts said at the end of February, spot gold prices in Mumbai had soared 38\% from a year ago to $\$ 575.27$ (28,750 rupees) per 10 grams (g) (nearly $\$ 1,850$ an ounce). They added that despite the strong rally in the precious metal last year, gold prices are expected to shoot up further in the coming years, and that it is this phenomenon that will attract more investors to the ETF route.

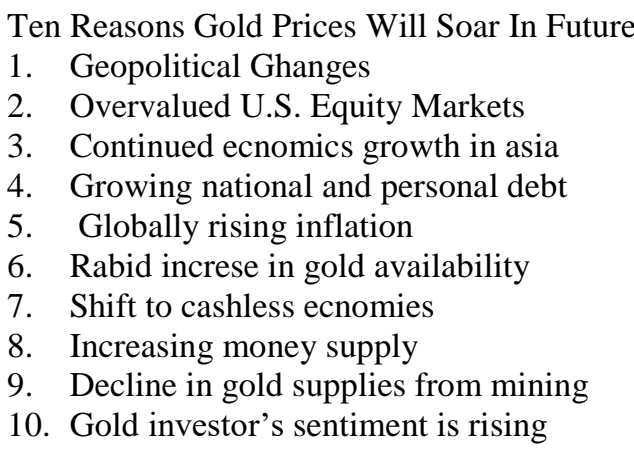

These are the 10 reasons that will push gold prices higher in future. And Mr. Sunil Tiwari said, "An Indian gold ETF provides a convenient, low-cost way for investors to bet on gold prices or hedge their portfolio exposures. ETFs here will continue to rise in popularity,"

According to data provided by the Association of Mutual Funds in India, the industry body of the 6.42 trillion rupees Indian mutual fund industry, gold ETFs recorded their highest monthly inflow ever in September 2016. A total of $\$ 246$ million (1,234 rupees crore) came into gold ETFs in the month of September alone, which was more than half of what the firm collected throughout the calendar year 2016.

Assets under management jumped 2.7 times over a year ago, to \$1.71B in September 2016, while the Indian gold price rose $35 \%$ and the Indian stock market tanked about $17 \%$ during the same period.

\section{Conclusion}

Going forward, the gold prices are likely to move upward slightly in the short term in the domestic territory given the increasing demand for jewellery and gold bars in India and China. Aside from seasonal demand, further depreciation in the value of rupee (offset by the regulatory relaxation- cut in the import duty from the current $10 \%$-encouraged by domestically improving trade deficit) will support the gold prices to some extent. A pick-up in gold buying by central bank may also contribute to a positive demand trend. However, strong dollar, stronger global economy, no sign of inflation, a continued tapering in the bond buying by Federal Reserve, declines in US equity risk premium, rising US real interest rates, and lack of interest of buyers would effect the global appeal for gold. Further, recovery in Europe, a positive GDP growth forecast of China, and an above average risk of disruptions in supply would be devastating factors for the gold. This paper explains the Gold ETFs soaring in future. And Analysts added that rising investment demand in India would prompt many fund houses to start new gold ETFs. With the uncertainty surrounding the equity markets in India still not over, they added investors' money will continue to come to invest in Gold ETFs 


\section{Reference}

[1]. Dr.Shivomseth, "Indian Investors Jump into Gold ETFs - Dec 2011 ”. Journal of Index Investing , 2 (2). Pg no - 132 - 143

[2]. Dr.V.Balaji and Dr.G.Rathika, “A STUDY ON THE PERFORMANCE OF GOLD ETFS - 2015” International Journal of Research instinct. Pg no - 1-9 Special issue - 2

[3]. Ms. Mallika Mathew. And Dr. M.M. Sulphey "Gold Exchange Traded Funds - A Behavioural Analysis of Retail Investors in Kerala" online article.

[4]. Dr.Prashanta Athma, "Gold ETFs: An emerging investment option: aria pacific journal of research in Business management, 2011, Vol.2, issue 1.

[5]. "Demand and supply". World Gold Council.gold.org

[6]. "Why invest in gold". nsegold.com

[7]. "World Gold Council-value-market intelligence-supply \& demand/recycled gold". Retrieved 2010-03-16. gold.org.

[8]. "The Industry Handbook: Precious Metals" Investopedia.

\section{WEBSITE}

[9]. Www.moneycontrol.com

[10]. www.nseindia.com

[11]. www.unesco.com

[12]. www.worldgoldcouncil.com

[13]. www.theaureport.com 